\title{
Snapshot on the Career and Employability of Islamic Studies Graduates in Malaysia
}

\author{
Abdul Aziz Abdullah, Mohd Saufee Anuar, Mohd Nazari Ismail
}

To Link this Article: http://dx.doi.org/10.6007/IJARBSS/v9-i11/6606

DOI: 10.6007/IJARBSS/v9-i11/6606

Received: 13 October 2019, Revised: 30 October 2019, Accepted: 06 November 2019

Published Online: 26 November 2019

In-Text Citation: (Abdullah, Anuar, Ismail, 2019)

To Cite this Article: Abdullah, A. A., Anuar, M. S., Ismail, M. N. (2019). Snapshot on the Career and Employability of Islamic Studies Graduates in Malaysia. International Journal of Academic Research in Business and Social Sciences, 9(11), 864-879.

Copyright: (C) 2019 The Author(s)

Published by Human Resource Management Academic Research Society (www.hrmars.com)

This article is published under the Creative Commons Attribution (CC BY 4.0) license. Anyone may reproduce, distribute, translate and create derivative works of this article (for both commercial and non-commercial purposes), subject to full attribution to the original publication and authors. The full terms of this license may be seen

at: http://creativecommons.org/licences/by/4.0/legalcode

Vol. 9, No. 11, 2019, Pg. $864-879$

Full Terms \& Conditions of access and use can be found at http://hrmars.com/index.php/pages/detail/publication-ethics 


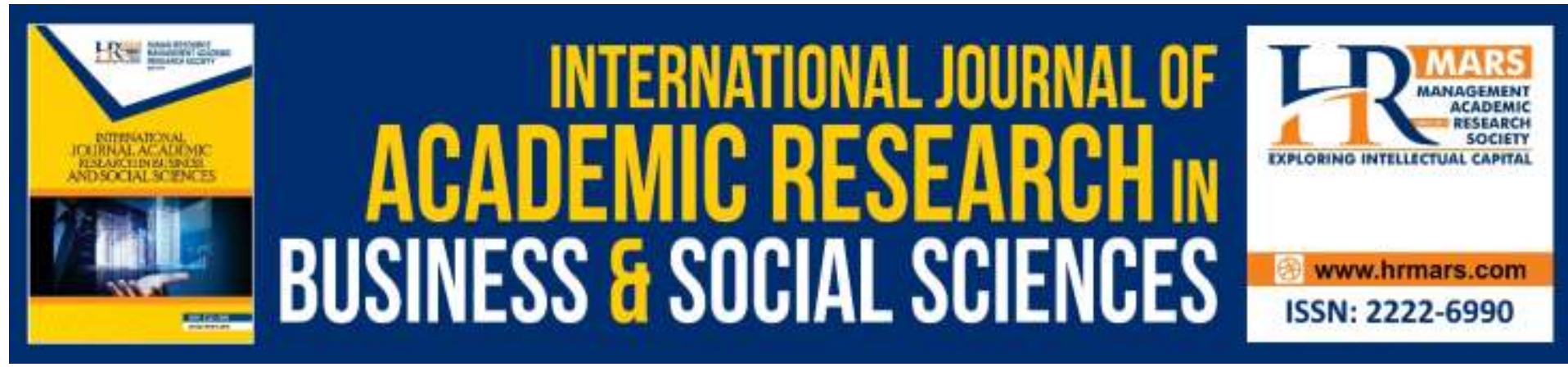

\title{
Snapshot on the Career and Employability of Islamic Studies Graduates in Malaysia
}

\author{
Abdul Aziz Abdullah, Mohd Saufee Anuar \\ Faculty of Business Management \& Accountancy, Universiti Sultan Zainal Abidin, Malaysia \\ Mohd Nazari Ismail \\ Faculty of Business and Accountancy, University of Malaya, Malaysia
}

\begin{abstract}
There are many challenges faced by the graduates of Higher Education Institutions (HEI) in getting themselves employed. One of which is the lack of soft skills which is directly related to employability. Thus improving the soft skills means increasing the graduate's opportunity to be employed. As such, employability of $\mathrm{HEI}$ graduates is one of the key agendas of the Ministry of Education (MOE). The objective of this paper is two prongs. First, is to highlight the scenario of Islamic Studies Graduates (ISGs) career and employability status after they have graduated from the Public Universities (PUs). The second, is to identify the elements of soft skills of these graduates who are employed in industry unrelated to their academic qualification. The first objective is achieved by obtaining data of both job career and employability rate of five PUs that offered Islamic Studies Programmes (ISPs). The data obtained from Univerisity Sains Islam Malaysia's (USIM's) career unit and Universiti Sultan Zainal Abidin's (UniSZA's) alumini were collected and analyzed descriptively. The second objective is achieved by interviewing the personnel of the organizations who employ these graduates. The data of the interviews will be transcribed and analyzed qualitatively by using Atlas. The first objective is achieved through two parts of the finding. The first part revealed that $40 \%$ of USIM's ISGs are employed in the professional and educational job. The other part of the finding interestingly revealed that out of five ISPs offered by PUs, UniSZA's two ISPs which Degree in Education (Islamic Studies) and Degree in Education (Primary Studies) achieved a 100\% employability for two consecutive years, 2015 and 2016. This finding concur with study conducted by Aini, Azizi and Yahya (2002); Fasan, Marcon, (2018). Besides the existing elements of soft skills crafted by the MOE, the finding of second objective is expected to reveal new emerging themes of ISGs soft skills. These themes are the elements that will form the structure of soft skills of the ISGs for PUs in Malaysia. It is expected that these soft skills would provide profound insight to researchers and educators alike what specific soft skills that ISG should have or acquire before they graduate from HEls, especially in the PUs. Thus, it is envisaged that the new structure of soft skills could perhaps be a guiding principles during the process of relooking and redesigning the current curriculum for ISPs offered at the Malaysian HEls.
\end{abstract}


Keyword: Employability, Soft Skills, Islamic Studies Graduates, Public Universities, Higher Educaton Institutions, Islamic Studies Programs, Ministry Of Education

\section{Introduction}

In the previous studies many researchers have proved that employability is one of the indicators to assess graduates ability to get a job immediately after they have completed their studies at the Higher Education Institutions (HEIs). One of these studies was by Hillage and Pollard (1999) where both of them considered employability as the function of an individual's asset and quality to gain from beginning employment, and conserve employment. It also means moving to the roles within the similar organization, acquire new employment if available, fasten and adequately fulfilling job satisfaction (Hillage \& Pollard, 1999).

The other study was by Thomsen (2009), where he emphasized that the skill differences are applicable for the labour gap but the long term changes on an unemployed person through the development of human capital is very limited. Although it is absolutely necessary to debate or discourse on the condition of the labor market, employability is still subjected to measure the ability for a person to be employed or otherwise (Thomsen, 2009). Therefore, it is of an ultimate importance that individual factors or skills required to measure the ability of $\mathrm{HEI}$ graduate to get a job should be given the right attention. However, the academic reputation still is not indicator for graduates to be hired if their soft skills are still at the lowest level of quality (Singh \& Singh, 2008; ).

\section{Definitions and Concepts of Employability Definitions of Employability}

In the 2012, Ministry of Higher of Education (MOHE), Malaysia launched the guideline of The National Graduate Employability Blueprint 2012-2017. This blueprint defined two important terms, namely employment and employability. In other words, MOHE definition of employability was based on literature suggesting the capabilities and effort of being marketable in the industry to fulfilling a job or career. Other researcher, for example Knight (2003) defined employability as an effort which was established by individual in term of achievements, understandings, personal attributes to being employed and success in job career. However, Hillage and Pollard (1999) defined employability on how people are able to gain initial job, retain it, and acquire new employment.

\section{The Concept of Employability}

The concept of employability can be considered by two perspectives, which is individual factor (attributes and skills) and personal circumstances (Hillage \& Pollard, 1999; Mcquaid \& Lindsay, 2005). It can also be further considered as a barrier for someone to apply or select a better job offered. According to UNESCO Bangkok (2012), the concept of employability refer to several situation such as competencies, job related competencies that makes arrangement to work, effort to develop individual career and attributes.

The other concept of employability is from the employer's perception and interest to measure the employability of a person will be based on psychological terms if the employee profile is known (UNESCO Bangkok, 2012). For example, good personality in social or interpersonal compatibility will give good perception from employer's side in term of dealing and rewarding these particular employees. As such, the result of employability depends on how to improve this stated personality. Employee's employability and employer's perception will be dynamic, if the abilities, expertise and the success in completing the assigned tasks is known. Thus, the 
ambition, work, ethic and the drive for an employee to work with commitment and accountability can develop a quality completed job.

\section{Soft Skills}

The finding from the study by Mahesh Kumar.K.R and Santhosh Kumar A.V (2016) revealed that the factor that influences employability among B-School graduates' soft skills are, individual competency and the ability to improve personal qualities. It is this soft skills that are required in order to get employed. This similar result is also supported by Nilsson (2010), where the qualities of graduates will be determine by acquiring employability's two skills, which are soft and hard skills. Skill differences among employees are the employability gap, whereby the number of unemployment can be reduced through employee actively engaged in employment programs (Thomsen, 2009; Azmy \& Zain, 2018). The impact of employee' soft skills on employability is relevant measure because most of researcher agreed soft skills can act as a tool or instrument to increase the abilities, competencies and qualities of personality. It is these skills that develop the employee future career.

\section{Comparison between Soft Skills and Hard Skills}

Soft skills are defined as a set of ability, knowledge and experience that enable someone to do something until it is perfect (Boyatzis \& Kolb, 1995). It can also be referred to as the personal ability that enable a person to touch or grasp the personality attributes, interacting politely in social situations, language, habits, affability, and mark people at every degree of interaction (Alex, 2009; Verma, 2013). Soft skills can also defined as the process of life involvement such as communication, making decision, solving problems and other related activities. On the other hand, hard skills focused on the technical knowledge that are easier to acquire such as certificate, diploma, degree, vocational skill and others (Mackey \& Tonkin, 2005),

Verma (2013) mentioned vividly that the relationship between softskills and hardskills. Soft skills are related to sociological term which refer to the behaviour or society that influence the ability while hard skills are acquired technically through the industries' demand. Soft skills are also skills acquire from the individual behavior whereby the strength of the personality can be developed from experience (Aquila et al. 2017). Nitin Bhatnagar and Mamta Bhatnagar (2011) defined soft skills and hard skills differently. Hard skills are addressed as technical abilities developed through education and practical training on applications of tasks. Soft skills, on the other hand, are the nature of interpersonal of individual that are more difficult subject to be defined and measured.

Subsequently, Balcar et al., (2011) summarized the tools to develope human capital of graduates with the topology of of skills as indicated in Table 5. This table describes both soft skills and hard skills in terms of generic skills and specific skills. The hard skills are technical and job specific skills while soft skills are non job specifics, intangible and hard to measure. Meanwhile, generic skills apply employees working in most companies who have both hard skills and soft skills. On the other hand, specific skills can also be both hard skills or soft skills which can be applied to employees of a certain companies who specialize in any industries where they are the experts. 
Table 5: Typology of Soft Skills

\begin{tabular}{|l|l|l|} 
& $\begin{array}{l}\text { Hard Skills: Technical, } \\
\text { job specific skill and } \\
\text { easier to observe }\end{array}$ & $\begin{array}{l}\text { Soft Skills: Non job } \\
\text { specific, intangible and } \\
\text { hard to measure }\end{array}$ \\
\hline $\begin{array}{l}\text { Generic Skills: Apply to most } \\
\text { companies }\end{array}$ & Generic: Hard Skills & Generic: Soft Skills \\
\hline $\begin{array}{l}\text { Specific Skills: Apply to certain } \\
\text { companies with specific expertise } \\
\text { and specialize in any industries that } \\
\text { they are the experts. }\end{array}$ & Specific: Hard Skills & Specific: Soft Skills \\
\hline
\end{tabular}

Source: (Balcar et al., 2011)

\section{Elements of Soft Skills Crafted by the Ministry of Higher Education}

One of the main agendas of the Ministry of Education (MOE) Malaysia is to impart the soft skills to students at $\mathrm{HEI}$. In this respect, the MOE has deligently crafted the elements of soft skills. Table 5 shows these elements that are required for students of HEls. The skills are incorporated into the programmers conducted at all PUs as well as private colleges and universities in Malaysia. The elements of soft skills categorized by the MOHE are as follow; communication, critical thinking and problem solving, team work, lifelong learning and information management, entrepreneur, ethics and professional morals and leadership. The description of each elements of soft skills is nicely presented in the table. For example, critical and problem solving provide the description on how students in HEI can think creatively, innovatively, analytically, and can apply the understanding and knowledge to a new problem and others. Eventually by having this skill, the students should be able analyse, improve, and create new idea and solve the problem. 
Table 5: Element of Soft Skills

\begin{tabular}{|c|c|c|}
\hline No. & $\begin{array}{l}\text { The Element of } \\
\text { Soft Skills }\end{array}$ & Description \\
\hline 1 & Communication & $\begin{array}{l}\text { This skill actually focuses on English and Malay language that relate } \\
\text { to how they can communicate, hear, and present. }\end{array}$ \\
\hline 2 & $\begin{array}{l}\text { Critical } \\
\text { Thinking and } \\
\text { Problem } \\
\text { Solving }\end{array}$ & $\begin{array}{l}\text { How they can think creatively, innovatively, analytically, and can } \\
\text { apply the understanding and knowledge to a new problem and } \\
\text { others. It will relate to identify and analyse, improve, and create new } \\
\text { idea and solve problem. }\end{array}$ \\
\hline 3 & Team Work & $\begin{array}{l}\text { How they can adapt with other people in diversity environment and } \\
\text { socio-culture to achive a same purpose. This skills refer to network, } \\
\text { understand, and know each other. }\end{array}$ \\
\hline 4 & $\begin{array}{l}\text { Lifelong } \\
\text { Learning and } \\
\text { Information } \\
\text { Management }\end{array}$ & $\begin{array}{l}\text { The strive of student to survive in getting a new knowledge or skills. } \\
\text { This is how they can find, manage, receive, a new information and } \\
\text { autonomy learning skill. }\end{array}$ \\
\hline 5 & Entrepreneur & $\begin{array}{l}\text { The ability to get a new opportunity, risk awareness, creative, } \\
\text { innovative that related to business and job. This is how to identify, } \\
\text { plan, and create the businesses. }\end{array}$ \\
\hline 6 & $\begin{array}{l}\text { Ethics and } \\
\text { Professional } \\
\text { Morals }\end{array}$ & $\begin{array}{l}\text { Able to implement the higher moral standard in professionalism and } \\
\text { social interaction such as to understand the impact the economics, } \\
\text { environmental, socio-culture, and good in decision making skills, } \\
\text { have on ethics,. }\end{array}$ \\
\hline 7 & Leadership & $\begin{array}{l}\text { Have a good personality as a leader such as knowledgeable, leader } \\
\text { of project, understand the responsibility in hierarchy level between } \\
\text { leader and members. }\end{array}$ \\
\hline
\end{tabular}

Sources: (Huzili, Zakaria and Salleh, 2012)

\section{Graduate Employability}

The issue behind the employability among Malaysian graduates in HEI is nothing new, and currently remains one of the Malaysian government ongoing concern. In the Malaysian parliament, the issue of Graduate Employability (GE) was constantly raised and debated. This issue is directly related to the unemployment rate of the country which in turn greatly impact the economic growth of the country. The Malaysian government has allocated a budget amount of RM 314.5 billion for year 2020 from RM 280.25 in 2019 (Ministry of Finance Malaysia, 2019 \& 2018) to the Ministry of Education (MOE) (before was known as MOHE). This shows a $10 \%$ increase from the previous year allocation. The increase in alloction shows clear indication that the government is concern with the development of education levels and the skills of the people of Malaysia. With the increase in spending, it is then expected that the unemployment rate will be reduced, thus increasing in the country's Gross Domestic Product (GDP).

Part of this spending is also meant to address the issue of GE through educational programs that need to be implemented at $\mathrm{HEI}$, an initiative by Ministry of Higher Education (MOHE), now known as the Ministry of Education (MOE). The Graduate Employability Program (GEP) is conducted by a collaboration between public and private agencies, with MOE acting as the 
coordinator. This program can thus enhance GE of students at PUs, private universities and colleges. Table 1 indicates the GEP initiated by MOE which appeared under different names, objectives, and the organizations which adopt the GEP.

Table 1: Graduate Employability Program

\begin{tabular}{|c|c|c|c|c|}
\hline No. & GEP & Objective Programs & Organizations & Author \\
\hline 1. & $\begin{array}{l}\text { Industrial Skill } \\
\text { Enhancement } \\
\text { Program } \\
\text { (INSEP) }\end{array}$ & $\begin{array}{l}\text { Technical and vocational } \\
\text { training for engineering } \\
\text { studies graduate }\end{array}$ & 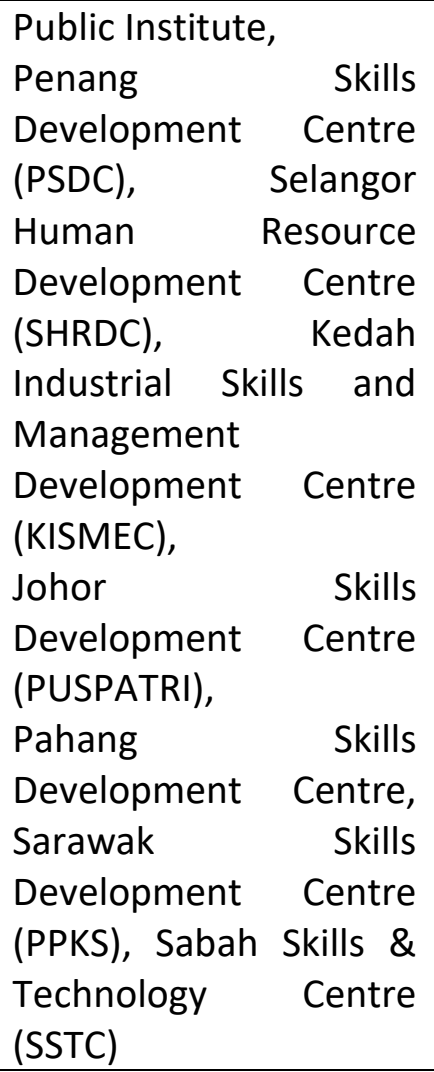 & $\begin{array}{l}\text { (Noraini } \\
\text { Kaprawi and } \\
\text { Anis } \\
\text { Mardhiyah } \\
\text { Azroai, 2009) }\end{array}$ \\
\hline 2. & $\begin{array}{l}\text { Upskilling } \\
\text { Program }\end{array}$ & $\begin{array}{l}\text { Develop graduate's skills } \\
\text { and provide opportunity } \\
\text { job to local fresh } \\
\text { graduates who studied in } \\
\text { engineering and } \\
\text { technology based on } \\
\text { industry attachment } \\
\text { programs. }\end{array}$ & $\begin{array}{lr}\text { TalentCorp } & \text { in } \\
\text { partnership } & \text { with } \\
\text { Knowledge.com } & \end{array}$ & $\begin{array}{l}\text { (Recoda, } \\
\text { 2016) }\end{array}$ \\
\hline 3. & $\begin{array}{l}1 \quad \text { Malaysia } \\
\text { Training } \\
\text { Scheme } \\
\text { (SL1M) }\end{array}$ & $\begin{array}{l}\text { Develop the employability } \\
\text { of graduates with job on } \\
\text { training (JOT) based on } \\
\text { soft skills which are } \\
\text { communication, creative } \\
\text { and analytical thinking, } \\
\text { organizational and } \\
\text { adaptability, value driven } \\
\text { professional and and } \\
\text { grooming and etiquette. }\end{array}$ & $\begin{array}{lr}\text { Most of them are } \\
\text { Govenrment } & \text { Link } \\
\text { Companies }(G L C) & \end{array}$ & $\begin{array}{l}\text { (Shamsuddin } \\
\text { et al., 2013) }\end{array}$ \\
\hline
\end{tabular}




\begin{tabular}{|c|c|c|c|c|}
\hline 4. & $\begin{array}{l}\text { Graduate } \\
\text { Employability } \\
\text { Management } \\
\text { Scheme } \\
\text { (GEMS) }\end{array}$ & $\begin{array}{l}\text { Develop marketability of } \\
\text { fresh graduates who are } \\
\text { unemployed to intensify } \\
\text { their employability based } \\
\text { on industry requirement } \\
\text { through job on training. }\end{array}$ & $\begin{array}{l}\text { Khazanah Group and } \\
\text { Talent Corp }\end{array}$ & $\begin{array}{l}\text { (Weekly } \\
\text { Bizehive, } \\
\text { 2016) }\end{array}$ \\
\hline
\end{tabular}

The four main GE programs are the Industry Skill Enhancement Program (INSEP), Upskillilng Program (UP), 1 Malaysia Training Scheme (SL1M) and Graduate Employability Management Scheme (GEMS). Each GE program has its specific and clear objective in addressing the issue of employability. For example, the SL1M program has the objective of the developing the employability of the graduates with job on training based of specify soft skills. This program is undertaken and assigned to specific government agencies and Government Link Companies (GLCs).

Thus, the MOE's GE programs has assisted graduates in developing and improve their employability and marketability through practical job experience skills and on the job training before they obtain a permanent job or be self-employed. HEls also provide numerous training activities through the curriculum and work based-learning (Kardi et al., 2009).

In the light of the theory of economic growth, innovation is described as the key driver for commercialization of the product (Tengku Nurhusni Tengku Ab Razak, 2013). This theory promotes development and production of new and innovative product which is expected to convince and lure foreign and local investor to invest in the local market. By doing so, existing market are expanded from the introduction of new product, thus boosting the economy of the country. The introduction of the product in the market is also expected to provide more job opportunities. Thus, this should reduce the rate of unemployment. This initiative can be considered as one of the way to increase the employability and marketability of the graduates.

\section{A Historical Overview of Higher Educational Institution for Islamic Studies Programs}

The proponents of Islamic Education can be deliberated by the historical overview of Higher Education Institution (HEI) for Islamic Studies Programmes (ISPs). It begins with the proposal on the development of Islamic institution in Malaysia which was the brainchild of Abdullah and Alwi Hj Hassan way back in the early 1950s. The outcome of the proposal was the establishment of Kolej Islam Malaya (KIM) in1955. KIM was earmarked as the first HEI in the country to offer ISPs (Rahman, Aziz \& Muda, 1993a). According to Ibrahim and Salleh (2008), Islamic Studies Department was first established in Universiti Malaya (UM) in 1959 this department was placed under the Art and Social Sciences Faculty until 1996. Thereof, the ISPs are now under the Islamic Academic, which currently has the largest number of students in Universiti of Malaya.

ISPs move forward and given greater boost where in 1970, Universiti Kebangsaan Malaysia (UKM) established its first Department of Islamic Studies. Consequently, Kolej Islam Malaysia (KIM) was dissolved after the establishing ISPs in UKM.

Nevertheless, the legacy of KIM was injected back into Kolej Universiti Islam Malaysia (KUIM) which was set up in May 2000. KUIM has since been renamed to Universiti Sains Islam Malaysia (USIM) (Yusof, 2015). 
Earlier on, the legacy of ISPs continued in 1976, where during the Seminar of Islamic Education of Malaysia II, the suggestion to setup another institution for teaching Islamic Studies educator was agreed by the MOE (Ab. Rahman, 1992). The suggestion comes true where Maktab Perguruan Islam (MPI) was formally established in 1977. The institutions of where all MPIs was upgraded to Institut Pendidikan Guru (IPG) on the $13^{\text {th }}$ July 2005 (Azilawani, 2011). Eventually, Universiti Pendidikan Sultan Idris (UPSI) was then established as the key HEI spearheading as the educator for ISPs. The establishment of this institution is based on legacy of Sultan Idris Teaching College (SITC) where it was then renamed as Institut Perguruan Sultan Idris (IPSI) in 1997 (Bahari, Othman \& Che Abdullah, 2011). Gracefully, IPSI was then upgraded and rebranded to Universiti Perguruan Sultan Idris (UPSI). Since then, UPSI remains as the main outstanding contributor to the nation's educators.

In the light of the establishment of KIM, UM, UKM, UPSI, and MPI, Universiti Islam Antarabangsa Malaysia (UIAM) or the International University Malaysia (IIUM) was established in 1983 (Abdallah, Hussien \& Hisham, 2011). It is UIAM or IIUM which retains as one of the Islamic institutions in this country which are seriously and deeply committed to the modern knowledge of Islamic values.

Similarly, the legacy of ISP continued by Abdul Hamid Abdullah and Embong Mohamad proposing the establishment of the renowned Kolej Agama Sultan Zainal Abidin (KUSZA) in 1980 (Rahman, Aziz, \& Muda, 1993). During that time, KUZA offered the Malaysian Certificate of Education (MCE) or the Sijil Pelajaran Malaysia (SPM), Sijil Tinggi Pelajaran Malaysia (STPM) and Diploma in ISPs. ISP continues to achieve greater heights by the transformation and upgrading of KUSZA to a PU where name evolved from Universiti Darul Iman (UDM) in 2006, and then to Universiti Sultan Zainal Abidin (UniSZA) in 2010 (Hamid, 2017).

In 2016, marked yet another legacy in the country's ISP where, the Prime Minister at that time, Datuk Seri Najib Tun Razak announced to all staff and students of Kolej Universiti Islam Sultan Azlan Shah (KUISAS), the upgrading of their kolej to a PU (Shaari, 2016). KUISAS is now known as Universiti Sultan Azlan Shah (USAS). The emergence of new private Islamic universities and colleges thereof (Ahmad, 2015) are the signs that ISP continues to become part and parcel of greater agenda of the government commitment towards upholding the constitution that Islam is religion of the state.

In 2019. UniSZA and Universiti Malaysia Terengganu (UMT) marks the latest controversial and well covered event in the history of education industry in Malaysia, that is, the merging of these two PUs into one entity (Maszlee Malik, 2019). If the first merger of these two HEls becomes a reality, then it expected that the glory of ISPs in UniSZA (once a upon time was KUZA) will be put under one flagship (faculty or college) combined with other niche area (s) of UMT. Perhaps, the outcome of this unique merger will put in place a new educational entity ever ready to compete locally and globally.

\section{Scenario of ISGS Job Career and Employability in Malaysia Pressing Employability Issue in Public Universities}

The pressing issue of graduate unemployment in Malaysia is not new. During 1990s, a research on graduates in Syariah, Academic of Islamic Studies from Universiti Malaya was conducted by Aini, Azizi \& Yahya (2002). The research revealed that some of the graduates were still unemployed few years after graduating. Interestingly, other ISG are employed mainly in the fields of education while the balance graduates landed in work unrelated to what they studied when they were at HEI. 
The Ministry of Youth and Sports make a statement of the need for HEI to conduct internship programs in different areas the students enrolled in (M. Nasaruddin, 2016). This is in line with addressing issue of ISG unable to get a job in area of the course that they took when they are at the univerisities or colleges. Job are not limited to ISG only but some of the jobs requires the combination of ISP and modern knowledge (Shukor (2008).

\section{Islamic Studies Graduates Job Career and Employability Rate}

The data of career in the form job cluster and employability rate of ISGs at five PUs that offered ISPs were collected. These universities were; UM, UKM, UIAM, USIM and UniSZA. However, the two PUs responded to the request for the information were UniSZA and USIM. The information on ISGs career was provided by USIM's job cluster while employability rate was shared by UniSZA's alumini.

\section{Islamic Studies Graduates Job Career}

The first part of the finding is on the ISGs job career organized by USIM. The job cluster for USIM's ISGs indicated the relationship between the numbers of ISG's against the job types from 2013 to 2016 as indicated in Figure 1. This data was obtained from USIM's career unit. It was the data of ISGs from the Faculty of Leadership and Management, the Faculty of Quranic and Sunnah Studies, and the Faculty of Syariah.

This figure showed that most USIM ISGs were employed in professional or eduction job (40\%). The rest got their opportunities to work in other jobs namely, the plant and machinery ( $0.63 \%)$, the police, military and other uniform (0.05\%), sales and service (15.25\%), and clerical (25.75\%). Interestingly, the combination of sale and service and clearical jobs comprised $40 \%$ of the total ISG employed in the industries. 
Figure 1: The Job Cluster of ISGs at USIM 2013-2016.

Basic Job
Plant and Machinery Operator and Installer Job
Vocational and Carpentry Skills Job
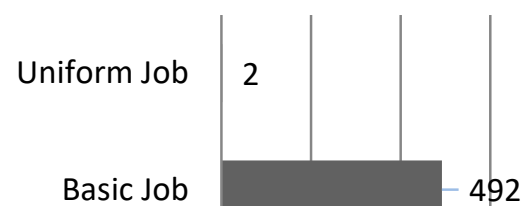

24

Vocational and Carpentry Skills Job

26

Agriculture, Forestry and Fishing Job

Sales and Services Job

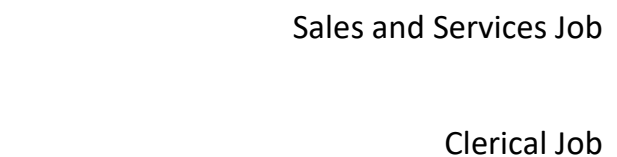

Associate Technician and Professional Job

Professional / Education Job
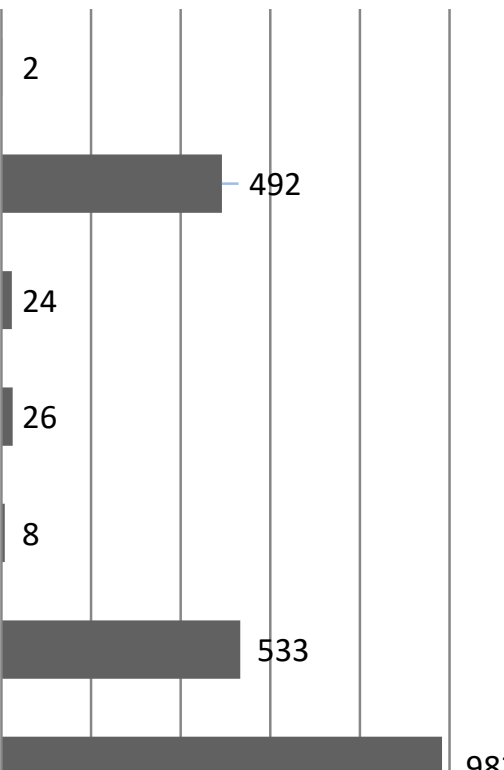

Manager

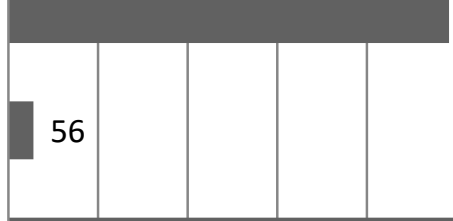

983

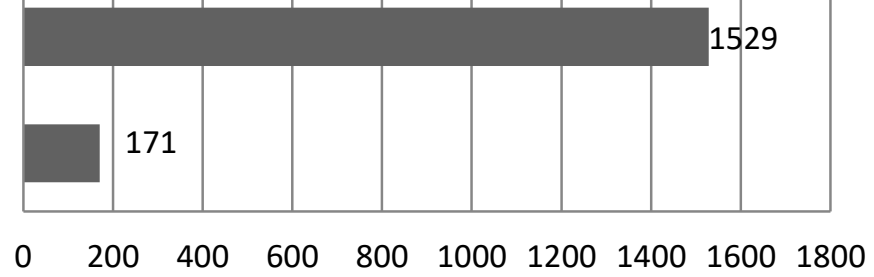

Source: (USIM Career Unit, 2017)

\section{Islamic Studies Graduates Employability Rate}

The other part of the finding were indicated in two tables, i.e Table 2 and Table 3. They were obtained from UniSZA's Faculty of Islamic Contemporary Studies (FICS). These tables provided a different landscape for ISG employability rate (UniSZA Alumni, 2017). They show the employment status of six different honours degree programs for the year 2015 and 2016. Degree in Education (Islamic Studies), Degree in Education (Primary Education), Degree in Islamic Studies (Dakwah), Degree in Islamic Studies with Couselling, Degree in Islamic Studies (Syariah), and Degree in Islamic Studies (Usuluddin) were the programs that were included in the paper. 
INTERNATIONAL JOURNAL OF ACADEMIC RESEARCH IN BUSINESS AND SOCIAL SCIENCES

Vol. 9, No. 11, November, 2019, E-ISSN: 2222-6990 @ 2019 HRMARS

Table 2: Employment Status of FICS Graduates for 2015.

\begin{tabular}{|c|c|c|c|c|c|c|c|c|c|c|c|c|}
\hline \multirow{3}{*}{$\begin{array}{l}\text { Field of Studies } \\
\text { in Faculty of } \\
\text { Islamic } \\
\text { Contemporary } \\
\text { Studies (FICS) }\end{array}$} & \multicolumn{10}{|c|}{ Employment Status } & \multirow{3}{*}{$\begin{array}{l}\text { Tota } \\
\text { I of } \\
\text { ISG }\end{array}$} & \multirow{3}{*}{$\begin{array}{l}\% \\
\text { GE }\end{array}$} \\
\hline & \multicolumn{2}{|c|}{ Employed } & \multicolumn{2}{|c|}{$\begin{array}{l}\text { Further } \\
\text { Studies }\end{array}$} & \multicolumn{2}{|c|}{$\begin{array}{l}\text { Develop } \\
\text { skill }\end{array}$} & \multicolumn{2}{|c|}{$\begin{array}{l}\text { Wait For } \\
\text { posting }\end{array}$} & \multicolumn{2}{|c|}{$\begin{array}{l}\text { Not } \\
\text { Working } \\
\text { Yet }\end{array}$} & & \\
\hline & $\begin{array}{l}\text { No } \\
.\end{array}$ & $\%$ & $\begin{array}{l}\text { No } \\
\text {. }\end{array}$ & $\%$ & $\begin{array}{l}\text { No } \\
\text {. }\end{array}$ & $\%$ & $\begin{array}{l}\text { No } \\
.\end{array}$ & $\%$ & $\begin{array}{l}\text { No } \\
.\end{array}$ & $\%$ & & \\
\hline $\begin{array}{l}\text { Education(Islam } \\
\text { ic Studies) } \\
\text { Hons. }\end{array}$ & 11 & $\begin{array}{l}100 . \\
00\end{array}$ & 0 & 0 & 0 & 0 & 0 & 0 & 0 & 0 & 11 & $\begin{array}{l}100 . \\
00\end{array}$ \\
\hline $\begin{array}{l}\text { Education(Prim } \\
\text { ary Education) } \\
\text { Hons. }\end{array}$ & $\begin{array}{l}24 \\
8\end{array}$ & $\begin{array}{l}100 . \\
00\end{array}$ & 0 & 0 & 0 & 0 & 0 & 0 & 0 & 0 & 248 & $\begin{array}{l}100 . \\
00\end{array}$ \\
\hline $\begin{array}{l}\text { Islamic Studies } \\
\text { (Dakwah) Hons. }\end{array}$ & 26 & $\begin{array}{l}41.2 \\
7 \\
\end{array}$ & 13 & \begin{tabular}{|l|}
20.6 \\
3 \\
\end{tabular} & 1 & 1.59 & 0 & 0 & 23 & $\begin{array}{l}36.5 \\
1 \\
\end{array}$ & 63 & $\begin{array}{l}63.4 \\
9 \\
\end{array}$ \\
\hline $\begin{array}{l}\text { Usuluddin with } \\
\text { Counselling } \\
\text { Hons. }\end{array}$ & 37 & $\begin{array}{l}34.2 \\
6\end{array}$ & 13 & $\begin{array}{l}12.0 \\
4\end{array}$ & 1 & 0.93 & 4 & $\begin{array}{l}3.7 \\
0\end{array}$ & 53 & $\begin{array}{l}49.0 \\
7\end{array}$ & 108 & $\begin{array}{l}50.9 \\
3\end{array}$ \\
\hline $\begin{array}{l}\text { Islamic Studies } \\
\text { (Syariah) Hons. }\end{array}$ & 18 & $\begin{array}{l}46.1 \\
5\end{array}$ & 3 & 7.69 & 0 & 0 & 3 & $\begin{array}{l}7.6 \\
9 \\
\end{array}$ & 15 & $\begin{array}{l}38.4 \\
6 \\
\end{array}$ & 39 & $\begin{array}{l}61.5 \\
4\end{array}$ \\
\hline $\begin{array}{l}\text { Islamic Studies } \\
\text { (Usuluddin) } \\
\text { Hons }\end{array}$ & 36 & $\begin{array}{l}48.0 \\
0\end{array}$ & 3 & 4.00 & 0 & 0 & 0 & 0 & 36 & $\begin{array}{l}48.0 \\
0\end{array}$ & 75 & $\begin{array}{l}52.0 \\
0\end{array}$ \\
\hline
\end{tabular}

Sources: (UniSZa Alumni, 2017)

In 2015 and 2016, two out of the six courses offered by UniSZA's FICS achieved a full employability. In 2015 alone, graduates from both Degree in Education (Islamic Studies) and Education (Primary Education) achieved a stunning $100 \%$ employability. This feat was successfully repeated in 2016.

In 2015 though, the employability rate for all the four programmes were between 50-54\%. In comparison, the percentage for Degree in Islamic Studies (Dakwah) and Islamic Studies (Syariah) decreased from $63.49 \%$ to $56 \%$ while in 2016 there was a decreased in employment rate from $61.54 \%$. To $58.4 \%$. The rest of the programs maintained a $50-55 \%$ employability rate. 
INTERNATIONAL JOURNAL OF ACADEMIC RESEARCH IN BUSINESS AND SOCIAL SCIENCES

Vol. 9, No. 11, November, 2019, E-ISSN: 2222-6990 @ 2019 HRMARS

Table 3: Employment Status of FICS Graduates for 2016.

\begin{tabular}{|c|c|c|c|c|c|c|c|c|c|c|c|c|}
\hline \multirow{3}{*}{$\begin{array}{l}\text { Field of Studies } \\
\text { in Faculty of } \\
\text { Islamic } \\
\text { Contemporary } \\
\text { Studies (FICS) }\end{array}$} & \multicolumn{10}{|c|}{ Employment Status } & \multirow{3}{*}{$\begin{array}{l}\text { Tota } \\
\text { I of } \\
\text { ISG }\end{array}$} & \multirow{3}{*}{$\begin{array}{l}\% \\
\text { GE }\end{array}$} \\
\hline & \multicolumn{2}{|c|}{ Employed } & \multicolumn{2}{|c|}{$\begin{array}{l}\text { Further } \\
\text { Studies }\end{array}$} & \multicolumn{2}{|c|}{$\begin{array}{l}\text { Develop } \\
\text { skill }\end{array}$} & \multicolumn{2}{|c|}{$\begin{array}{l}\text { Wait For } \\
\text { posting }\end{array}$} & \multicolumn{2}{|c|}{$\begin{array}{l}\text { Not } \\
\text { Working } \\
\text { Yet } \\
\end{array}$} & & \\
\hline & No & $\%$ & No & $\%$ & No & $\%$ & No & $\%$ & No & $\%$ & & \\
\hline $\begin{array}{l}\text { Education(Islami } \\
\text { c Studies) Hons. }\end{array}$ & 18 & $\begin{array}{c}100 . \\
00\end{array}$ & 0 & 0 & 0 & 0 & 0 & 0 & 0 & 0 & 18 & $\begin{array}{c}100 . \\
00\end{array}$ \\
\hline $\begin{array}{l}\text { Education(Prima } \\
\text { ry Education) } \\
\text { Hons. }\end{array}$ & $\begin{array}{c}19 \\
7\end{array}$ & $\begin{array}{c}100 . \\
00\end{array}$ & 0 & 0 & 0 & 0 & 0 & 0 & 0 & 0 & 197 & $\begin{array}{c}100 . \\
00\end{array}$ \\
\hline $\begin{array}{l}\text { Islamic Studies } \\
\text { (Dakwah) Hons. }\end{array}$ & 33 & $\begin{array}{c}44.0 \\
0\end{array}$ & 7 & 9.33 & 1 & 1.33 & 1 & 1.33 & 33 & $\begin{array}{r}44 . \\
00\end{array}$ & 75 & $\begin{array}{c}56.0 \\
0\end{array}$ \\
\hline $\begin{array}{l}\text { Usuluddin with } \\
\text { Counselling } \\
\text { Hons. }\end{array}$ & 17 & $\begin{array}{c}47.2 \\
2\end{array}$ & 0 & 0 & 1 & 2.78 & 0 & 0 & 18 & $\begin{array}{c}50 . \\
00\end{array}$ & 36 & $\begin{array}{c}50.0 \\
0\end{array}$ \\
\hline $\begin{array}{l}\text { Islamic Studies } \\
\text { (Syariah) Hons. }\end{array}$ & 49 & $\begin{array}{c}39.8 \\
4 \\
\end{array}$ & 17 & $\begin{array}{c}13.8 \\
2 \\
\end{array}$ & 5 & 4.07 & 1 & 0.81 & 51 & $\begin{array}{l}41 . \\
46\end{array}$ & 123 & $\begin{array}{c}58.5 \\
4 \\
\end{array}$ \\
\hline $\begin{array}{l}\text { Islamic Studies } \\
\text { (Usuluddin) } \\
\text { Hons }\end{array}$ & 24 & $\begin{array}{c}36.3 \\
6\end{array}$ & 9 & $\begin{array}{c}13.6 \\
4\end{array}$ & 2 & 3.03 & 1 & 1.52 & 30 & $\begin{array}{c}45 . \\
45\end{array}$ & 66 & $\begin{array}{c}54.5 \\
5\end{array}$ \\
\hline
\end{tabular}

Sources: (UniSZA Alumni, 2017)

\section{Conclusion}

This paper provides the scenario for career opportunities of USIM's and UniSZA ISG'S employability status. In the case of career opportunities, the data reflects the status of USIM's ISG job career in different organization. More than $40 \%$ of the ISGs are employed in professional or education area. The other extreme are the uniform job $(0.05 \%)$ and plant and machinery operator skills jobs (0.02\%). It was interesting to note that Degrees in Education (Islamic Studies) and Degree in Education (Primary Schools) achieved 100\% employability in 2015 and 2016. It seems from both career opportunities and employment status matches the result career opportunities in professional in education for USIM and the $100 \%$ employability degree in Education from UniSZA. This finding concur with the study conducted by Aini, Azizi \& Yahya (2002). Thus, ISPs that focus on education via the Degree Program fits in the career in education and professional job as in the data provided by the USIM's career units.

It can be concluded that more $40 \%$ of USIM's ISGs have the opportunity to work in their area of academic qualification while the other $60 \%$ ISGs are not as fortunate. Likewise, the holders of Degree in Education for both Islamic Studies and Primary Schools obtained exceptionally high 100\% employability compared to other ISPs offered by UniSZA in 2015 and 2016, with 
employability rate of only $50-64 \%$. It is rather interesting to note that about $36-50 \%$ of UniSZA's ISGs are either employed in unrelated to their academic qualification. The other possibilities were that UniSZA's IGSs were self-employed with career as enterpreneurs or pursue their post graduate studies at HEl's.

The second of part of this study will be presented in the forthcoming paper. In this paper, it is expected that soft skills crafted by MOHE and new emerging soft skills from the employers of the organizations that employ ISGs will be able to highlight the issues of employability and marketability among HEls graduates. The acquiring of these soft skills is crucial for students who are going to be enrolled in the ISPs. By acquiring these skills, the ISGs of HEI can develop their career in organization, once they graduate. The newly emerged softskills together with existing soft skills crafted by MOE (communication, critical thinking and problem, team work, lifelong learning and information management, entrepreneur, ethics and professional morals and leadership) will form the structure of softkills of ISGs. This structure is expected to provide a better approach to deal with employability of ISGs in UPs. In this respect, new elements in the structure of employability for ISGs will be able to provide the HEls additional variables when designing activities in ISPs so that these skills can be developed and acquire when students at HEI. In addition, these soft skills existed in most ISG will be a value added to their existing soft skills when they apply for a job. Thus, this further study is expected to reveal the empirical evidence and the justication as to why ISGs are well accepted to work in organizations and industries which are not in line with their academic qualification.

ISGs should be open minded for not only to look for jobs limited to Islamic Studies based organization but also be able to identify and select jobs that combine ISP with modern knowledge as mentioned by Shukor (2008). Bearing this in mind, it will be highly likely that ISGs would be able to compete with graduates from other majors in this competitive employment market.

\section{Acknowledgements}

This paper has benefited greatly from a grant awarded by Ministry of Higher Education in 2014, namely Research Acculturation Collobarative Effort (RACE). Hence we kindly express our deepest gratitude to the Research Management, Innovation and Commercialization Centre (RMIC) of Universiti Sultan Zainal Abidin, Terengganu, Malaysia for their assistance, without which an empirical study of this magnitude would not have been possible.

\section{References}

Azmy, N. binti, \& Zain, A. Z. bin M. (2018). Engineering Technology Curriculum Development: Bridging the Gap Between Academia-Industry Through Undergraduate Final Year Project. International Journal of Academic Research in Progressive Education and Development, 7(4), 459-467.

Rahman, I. (1992) Pendidikan Islam Di Malaysia. Bangi: Universiti Kebangsaan Malaysia.

Rahman, I., Aziz, A. @ A. M. \& Muda, M. Y. (1993a) Isu-Isu Pendidikan Islam Di Malaysia: Cabaran \& Harapan. Kolej Agama Sultan Zainal Abidin. 
INTERNATIONAL JOURNAL OF ACADEMIC RESEARCH IN BUSINESS AND SOCIAL SCIENCES

Vol. 9, No. 11, November, 2019, E-ISSN: 2222-6990 @ 2019 HRMARS

Abdallah, S. S., Hussien, S. \& Hisham, N. A. (2011) 'The Experience of Islamization of Knowledge at the International Islamic University Malaysia', New Intellectual Horizons in Education, pp. 91-111.

Ahmad, M. Y. (2015) Institusi Pendidikan Al Qur'an Di Malaysia. Dewan Bahasa dan Pustaka.

Alex, K. (2009) 'Soft Skills', in S, Chand and company. New Delhi.

Bahari, K. A. et al. (2011) 'JHEPA: Ke Arah Pembangunan Modal Insan', JHEPA UPSI, 5(1), pp. 179198. doi: 10.3390/rel5010179.

Boyatzis, R. E. and Kolb, D. A. (1995) 'Excecutive Skills Profile', Journal of Managerial Psychology, 10, pp. 3-17.

Hamid, N. A. (2017) 'UniSZA's Staff Cash Waqf : The Impact to Social and Economic Development of Terengganu State', Pertanika Journals, 25, pp. 239-254.

Hillage, J. \& Pollard, E. (1999) 'Employability: developing a framework for policy analysis', Labour Market Trends, 107(85), pp. 83-84. Available at: https://www.education.gov.uk/publications/eOrderingDownload/RB85.pdf.

Huzili, H., Zakaria, A., and Salleh, M. S. (2012) 'Memperkasakan Mahasiswa Kejuteraan Menerusi Penerapan Kemahiran Insaniah (Soft Skills)', Oxford Reference Online, pp. 583-596. Available at:

http://datubazes.lanet.Iv:2148/view/10.1093/oi/authority.20110803100516309\%5Cnhttp ://datubazes.lanet.Iv:2148/view/10.1093/acref/9780199298761.001.0001/acref9780199298761.

Ibrahim, M. \& Salleh, K. (2008) Islam Pasca Kemerdekaan. Karisma Publication Sdn Bhd.

Kardi, N., Awang Hashim, R. and Mohd Yusoff, N. (2009) 'Enhancing Employability Initiatives: Malaysia Experience', The 2009 ASAIHL Conference, pp. 7-18. Available at: http://www.kln.ac.lk/uokr/ASAIHL/Malayasia.pdf.

Fasan, M., Marcon, C. (2018). Accounting Choice under IFRS: The Role of Accounting Tradition and Managerial Opportunism, International Journal of Academic Research in Accounting, Finance and Management Sciences 8 (3): 209-223.

Knight, P. (2003) Assessment, Learning and Employability. UK: McGraw-Hill Education.

Nasaruddin, P. (2016) 'Gilap Kualiti Graduan Pengajian Islam', Berita Harian, 3 August.

Mackey, S., \& Tonkin, L. (2005) 'Living Well, Working Smart - Soft Skills For Success', in McCown, V. (ed.) Book Publisher Network. USA.

Kumar, K. R., \& Kumar, A. V. (2016) 'Impact of Soft Skills Training on Employability Competency in Sims, Bangalore: A Study With Reference To B-School Graduates', International Journal of Research in IT \& Management, 6(3), pp. 10-17.

Malik. (2019) Penyata Rasmi Parlimen Dewan Rakyat Parlimen Keempat Belas Penggal Kedua Mesyuarat Ketiga. Wilayah Persekutuan.

Mcquaid, R. W. \& Lindsay, C. (2005) 'The Concept of Employability', Urban Studies, 42(2), pp. 197-219. doi: 10.1016/j.buildenv.2006.10.027.

Yusof, A. (2015) Institusi Pendidikan Al Qur'an Di Malaysia. Kuala Lumpur: Dewan Bahasa dan Pustaka.

Nilsson, S. (2010) 'Enhancing individual employability: the perspective of engineering graduates', 
Education + Training, 52(6/7), pp. 540-551. doi: 10.1108/00400911011068487.

Bhatnagar \& Bhatnagar. (2011) Effective Communication and Soft Skills: Always learning. India: Pearson Education India.

Aini, A., Azizi, C. S. \& Yahya, M. H. (2002) 'Kerjaya Graduan Sarjana Muda Syariah, Akademi Pengajian Islam, Universiti Malaya (1996-2002)', University of Malaya.

Kaprawi, N., \& Azroai, A. (2009) 'Towards a Sustainable Continuing Technical and Vocational Education (TVE) Programmes in Higher Education Institution (HEI) in Malaysia', International Conference on Teaching and Learning in Higher Education, pp. 46-54.

Recoda. (2016) 'Human Capital Development', (January), pp. 231-237. Available at: http://www.recoda.com.my/invest-in-score/human-capital-development/.

Shaari, S. (2016) 'KUISAS Dinaik Taraf Jadi Universiti Awam', Utusan Malaysia, 10 June. Available at: $\quad$ http://www.utusan.com.my/pendidikan/kuisas-dinaik-taraf-jadi-universiti-awam1.340771.

Shamsuddin, A. (2013) 'Graduate unemployment: The awareness and perception of graduates towards government's initiatives', International Journal of Business, Economics and Law, 3(1), pp. 15-24.

Shukor, H. A. (2008) 'Pembangunan Muslim Hadhari Melalui Pendidikan Islam Era Globalisasi. Dalam Pembangunan Pengajian Tinggi Islam di Malaysia.', Bandar Baru Nilai: USIM.

Singh, G. K. G. \& Singh, S. K. G. (2008) 'Malaysian Graduates' Employability Skills', UniTAR eJournal, 4(1), pp. 15-45. doi: ISSN 1511-7219.

Thomsen, S. L. (2009) 'Explaining the employability gap of short-term and long-term unemployed persons', Kyklos, 62(3), pp. 448-478. doi: 10.1111/j.1467-6435.2009.00445.x.

UniSZa Alumni (2017) 'Status Pekerjaan Graduan Mengikut Peringkat Pengajian Dan ljazah Dianugerahkan UniSZa 2015 \& 2016'.

USIM Career Unit (2017) 'Graduan Pelajar Islam'. Nilai: Counseling Psychology \& Career Unit, USIM.

Verma, S. (2013) 'Personality Development And Soft Skills For Class XI', in Goyal Brothers Prakashan. First Edit. New Delhi: Goyal Brothers Prakashan Educational Publisher.

Bizehive, W. (2016) 'Building and enhancing Malaysia's human capital Transforming Sarawak's workforce', Bizehive Weekly, January, pp. 8-9. Available at: https://s3-ap-southeast1.amazonaws.com/talentcorpbucket/assets/multimediams/media/BIZHIVE Weekly_Building and Enhancing Malaysia\%27s Human Capital (3 - 9 Ja....pdf. 